\title{
Occupational and Environmental Medicine
}

\section{Editorial}

\section{Obituary of Ronald Epey Lane 1897-1995}

\author{
CBE MSc(Manchester) MD(London) FRCP DIH (Hon) FFOM: Editor Br f Ind Med 1963-65
}

In 1945 Ronald Lane was the first Professor of Occupational Health to be appointed in Great Britain. He had already made his mark as a young physician who eliminated an epidemic of lead poisoning in a factory making electric accumulators.

He was educated at Simon Langton School, Canterbury. In the 1914-18 war, he spent three years in the Royal Flying Corps and RAF, was demobilised in 1919 , and went to Guy's Hospital where he held house appointments and in 1925 took the MRCP, which he always stressed proved invaluable in the practice and teaching of occupational medicine. He went into general practice in Nottingham where he met Leonard Lockhart, Chief Medical Officer at Boots, who got him so interested in industrial medicine that he applied for a post as Medical Inspector of Factories. It was E R A Merewether who had more experience in preventive medicine who got the job but J C Bridge, the Senior Medical Inspector was so impressed by Lane that he advised the Chloride Electrical Storage Company to appoint him. In spite of new regulations to enforce better conditions, their notified cases of lead poisoning were increasing. In despair the managing director of the Chloride Company took the unusual step of appointing Lane and ceasing to rely on the examining surgeon appointed by the Factory Inspectorate, to deal with a problem that was out of control.

Lane, who had no training or experience in occupational medicine, used his clinical skills to monitor workers for evidence of lead absorption and set his own limit for lead in air, based on clinical findings. The result was dramatic. After his appointment, the Chloride Company, which produced $90 \%$ of the lead batteries made in the United Kingdom, was responsible for only $6 \%$ of all cases occurring in this industry between 1930 and 1961 . He gave something more than clinical skills to the solution of this problem. He stressed that an occupational physician needed to educate both management and workpeople in their responsibilities for promoting health at work.

During the 1939-45 war Ronald Lane had organised training courses for factory doctors and nurses through the Extramural Department of Manchester University. When the Nuffield Foundation funded Manchester's new academic Department of Occupational Health, he was the obvious choice to fill the Chair, as he had the rare experience of being a factory doctor and a consultant physician at the Salford Royal Hospital. This experience as a consultant physician, together with his clinical skills in dealing with workplace health problems enabled him to establish his Department within the University's Department of Medicine. One of Manchester's main contributions to occupational medicine was through Lane's impact on the medical undergraduates, by direct teaching on patients and indirectly by his influence on young registrars who play an important part in student training. He had a down to earth approach to occupational health. His aim was to get patients with work related illness or employment problems back to work for their own benefit. Doctors who were to practise occupational medicine should, he believed, spend three months as an operative on the shop floor, learning first hand about the hazards to health. Medical staff at Manchester University were told to keep their feet on the ground if they got too airy-fairy. His direct teaching of students was inspired. This was something he could not achieve in his didactic lectures because his power to communicate was not as a speechmaker, but through personal contact and compassion. Thus he influenced his staff in the factory and the university who loved and respected him. While he was very much alive with his finger on the pulse of occupational health, his friends and old colleagues endowed a lecture room in his name in the Department he had created.

Ronald Lane gave much of his time to Government committees on occupational health, rehabilitation, prescription of industrial disease and to international committees of the World Health Organisation and International Labour Office. Towards the end of his active professional career at an age when most people would be looking forward to retirement, he agreed to take on the editorship of this Journal until a successor to Leslie Norman could be found.

Ronald Lane was a man of integrity and compassion, and a highly competent general physician who made an outstanding contribution to Occupational Health during its formative years. Winifred, his first wife died in 1981 and Ida, his second wife died in 1991 . He is survived by his son, Peter, a consultant dermatologist in Canada.

RICHARD SCHILLING 